\title{
The Analysis of Major Credit Risk Factors - The Case of the Vietnamese Commercial Banks
}

\author{
Nguyen Thuy Duong ${ }^{1} \&$ Tran Thi Thu Huong ${ }^{1}$ \\ ${ }^{1}$ Banking Academy of Vietnam, Vietnam \\ Correspondence: Dr. Nguyen Thuy Duong, Banking Academy of Vietnam, Vietnam.
}

Received: October 25, 2016

Accepted: November 14, $2016 \quad$ Online Published: December 8, 2016

doi:10.5430/ijfr.v8n1p33

URL: http://dx.doi.org/10.5430/ijfr.v8n1p33

\begin{abstract}
In this study, we tried to identify determinants of the credit risks at Vietnamese commercial banks. By applying the quantitative model using the unbalanced panel data of 20 banks in the period from 2006 to 2014, coupled with surveying the dependent variable, that is non-performing loan (NPL), in order to express the credit risks in business activities of commercial banks, the study has made conclusions on two groups of determinants that may have influence on the credit risks: (i) Bank-specific determinants and (ii) macro determinants. Specifically, the quantitative results showed that most correlations affirmed the accuracy of theory and relevant previous research findings, of which some notable results obtained by the author included: (i) For bank-specific determinants, the credit risks were highly inertia, requiring the continuous management of credit risks. Besides, the bank size and market share negatively influenced the credit risks of commercial banks due to adverse impacts on the readiness of acceptance of risks in business activities. In addition, the rapid credit expansion, ineffective capital use and credit control and management also caused future credit risks. (ii) For macro determinants, the estimated results re-affirmed the relationship between impacts of economic cycles though GDP growth and credit risks of commercial banks. (iii) Additionally, the study has not found any correlation between the effectiveness of general management, real lending interest rate and credit risks in business activities of Vietnamese commercial banks.
\end{abstract}

Keywords: credit risk, non-performing loan, macro determinants, micro determinants

\section{Credit Risk}

As a financial intermediary in the economy, credit capital flows of banks always play such an important role in the growth and development the national economy, especially for developing countries. The effective control of credit capital flows, reduction of credit risks will enhance the efficient uses of capitals and accelerate the capital flows, thereby promoting the economic development. Therefore, credit risk is one of top concerns and interests of managers and policy makers. First of all, this study will clarify concepts of credits risks in the banking business.

According to Thomas P.Fitch, Credit risk is the risk that occurs when borrowers fail to meet their contractual obligation to repay a debt in accordance with agreed terms. Along with interest rate risk, it is the main risk in lending activities of commercial bank (Dictionary of banking terms, Barron's Edutional, Inc, 1997)

Timothy W.Koch showed that one commercial bank hold productive assets, risks may occur when customers fail to make timely repayment - it means that customers are unable to pay principal and interest under their signed contracts. Credit risk means any potential changes of net income and market value of the capital arising from customers' failure in payment or late payment (Bank management, University of South Carolina, The Dryden, 1995, page 107).

Brajovic Henuievan Greuning - Sonja Bratanovic defined that: Credit risk is defined as that borrowers fail to pay interests or repay the principal compared to required time as set out in credit contracts. This is the inherent natures of business activities of commercial banks. Credit risk is the delay of repayment or in worse cases, the complete failure in payment. This causes problems for cash flows, affecting the liquidity of commercial banks (The World Bank)

A Saunders and H.Lange defined that: Credit risk is a potential loss when a commercial bank provides a credit loan to a customer, or the ability that intended income flows from loans of commercial banks cannot implemented fully both quantity and required duration (Financial institutions management - A modern perspective).

In the document "Banking Technology for developed countries" credit risk is defined as economic loss of banks due to a group of customers who fail to repay loans from the banks. 
In circular No. 02/2013/TT-NHNN issued by the State bank of Vietnam, credit risk is loss potentially caused to credit institutions, foreign bank's branches when customers do not or unable to perform part or the whole obligations in accordance with commitments.

From the above definition, credit risk may be broadly defined as risk of financial loss (direct or indirect) when the borrowers do not perform their payment obligation in accordance with commitments or they are unable to pay back.

\section{Indentification and Analysis of Credit Risk Factors}

The paper focuses on answering three following questions:

1. What is the relationship between macro factors (Economic cycle, real interest rates, and inflation) and credit risk in Vietnamese commercial banks?

2. What is the relationship between micro factors (Credit risks of the previous period, profitability, cost management effectiveness, capital structure, size of bank, credit growth) and credit risk in Vietnamese commercial banks?

3. In the micro factors, which factor has the greatest impact on the credit risks?

\subsection{Data}

Data used in the quantitative model is the annual data of 20 commercial banks in Vietnam in nine years in the period 2006-2014 taken from BankScope database of BVD and added with information from banks' annual reports. These banks selected as research sample shall ensure the existence and operation until 2014 with consecutive statistics in at least 6 years. In addition, banks are required to ensure the representation for Vietnamese commercial banks system with 3 major groups including group of state-owned commercial banks; group of Joint stock commercial banks and group of foreign or joint venture banks. The selected banks shall own total property accounting for more than $85 \%$ of value of total property of the entire system. With macro statistics, researchers will use metric calculation and implement collection from statistical reports and data announced by The General Statistics Office of Viet Nam, the State Bank of Viet Nam, International Monetary Fund (IMF) and World Bank in the same period.

\subsection{Research Variables}

\subsubsection{Dependent Variables}

Credit risk is potential loss which is likely to occur for credit organizations when clients refuse or fail to make payment of principal and/or interest on due date as undertaken with Commercial banks (Circular No. 02/2013/TT-NHNN). And credit activity of commercial banks will have to face larger risk when quantity of loans and credit outstanding balance show sign of late payment of principal and/or interest from clients.

In most of studies on credit risk in business of commercial bank system, the ratio of non-performing loans is often widely used to reflect credit quality of commercial banks (Salas and Saurina, 2002; Jimenex and Saurina, 2007; Louzis et al., 2012;...). Particularly, according to Reinhart and Rogoff (2010), Nkusu (2011) and Louzis et al. (2012), the ratio of NPLs representing credit risk in banking business can be used as a reliable criterion to take early alert over banking crisis which can result in economic crisis. This is explained by a crisis in banking activities originating from difficulty in satisfying the commercial banks' demand for liquidation, arising mainly out of difficulty in recovering principal and/or interest in credit activities.

We make a choice of the ratio of Non-performing loans (NPLs) calculated from financial statements of commercial banks and criterion of Impaired loans/Gross loans from reports of Bankscope datasets of Vietnamese commercial banks in the 2006-2014 period. In which, categorization of debts at commercial banks are carried out under the Circular No. 02/2013/TT-NHNN issued by State bank of Vietnam on debt categorization, extraction and utilization of credit risk provisions. This will ensure the uniformity in the ratio of NPLs at commercial banks during conducting research.

\subsubsection{Explanatory Variables}

Explanatory variables are divided into two groups: group of micro-economic variables and group of macro-economic variables. Whilst the group of micro-economic variables shows effect of commercial banks' operational characteristic, management capacity and features on credit risk in business, micro-economic variables are applied to the model with an aim of clarifying economic environment's effects on the ratio of NPLs, repayment capacity as well as credit decision of commercial banks. Variables are selected on the basis of past studies on factors affecting credit risk in banks' business.

\subsubsection{Macro-economic Variables}


Macro-economic determinants are selected to present macro-economic environment's effects on commercial banks' repayment capability as well as credit behavior, thereby affecting credit risk in banks' business.

Economic cycle: Banking credit and economic cycle always have a close link. In the theory of economic cycle and consumption model developed by Modigliani and Miller (1967), in the period of economic growth, enterprises and individuals will be easier in payment of loans from commercial banks because of better investment opportunity and business prospect. Adversely, in the period of economic downturn, economic agents will face more difficulties in business and use of loans, thereby making negative effects on repayment. This is proved through experimental studies in many countries around the world such as studies conducted by Salas and Saurina (2002); Jimenez and Saurina (2005) with the system of Spanish commercial banks, Fisher et al., (2002) with the system of American and Canadian commercial banks; Louzis et al., (2010) with the system of Egyptian commercial banks or Quagliarello's (2007) with the system of Italian commercial banks over the 1985-2002 period. Similarly, the authors select GDP growth $\left(\mathrm{GDP}_{\mathrm{t}}\right)$ to present economic cycle's effects on credit risk at Vietnamese commercial banks.

Real interest rate: Real interest rate shows prices of loans and real costs which are incurred by economic agents. For this reason, the change of real interest rate will influence individuals' and enterprises' debt payment to commercial banks. Also, together with decline in GDP growth, high unemployment rate, the increase in real interest rate and high inflation rate is considered an alert for banking crisis (Demirguc-Kunt and Detragiache, 1998). The previous experimental studies also find the existence of strong correlations between real interest rate and credit risk at commercial banks such studies conducted by Bofondi and Ropele (2011) or Berge and Boye (2007) and Louzis (2010)... A win-win correlation between real interest rate (Realir $\mathbf{t}_{\mathbf{t}}$ ) and credit risk (NPLs $\mathbf{s}_{\mathbf{t}}$ ) is expected by the author.

Inflation: There would be likely to exist win-win or lose-lose relations between inflation and credit risk in commercial banks' business. Increased inflation will reduce real costs incurred by economic agents from debts, thereby raising clients' solvency. On the contrary, increased inflation also makes negative effect on economic agents' real income and creates more difficulties in completing their repayment obligation under commitments with

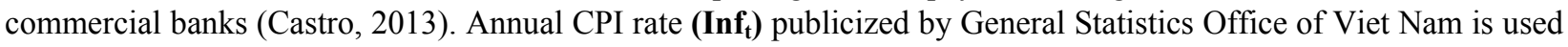
to present inflation rate.

\subsubsection{Bank-specific Variables}

Apart from macro-economic variables representing business environment of commercial banks, bank-specific variables indicate effects of business features and operational capacity of each commercial bank on credit risk in its business.

Credit growth: Credit growth rate is deemed as one of the variables which affects and soon warns credit risk in banks' business. Fisher (1933) and Keynes (1934), in their financial accelerator mechanism, pointed out that during the period of rapid credit growth, capital flows which are constantly poured into the economy will result in the continuous increase in property value, the better criteria and benefits of economic agents. This causes the easy issue of credits with higher degree of credit risk. At the same time, rapid credit growth often occurs in the period of fierce competition among commercial banks, causing the reduction in credit standards and the increase in credit risk in the future (Dell Ariccia and et al., 2009; Salas and Saurina, 2002; Jimenez and Saurina, 2007). Simultaneously, Berger et al., (2004) also claim that fast credit growth will influence commercial banks' management of risk and client information, thereby causing the increase in credit risk. The author uses growth rate of lending items acting for credit growth (Bankcrgr $\mathbf{B i t}_{\mathrm{it}}$ ) of commercial banks in this research.

Managerial capacity: In addition to causes arising out of economic environment as well as business efficiency of clients, credit risk can be also originated from subjective causes of commercial banks' activities. In case of improvement in commercial banks' operational and managerial efficiency, information and risk management will minimize credit risk in commercial banks' business. There are two variables selected for representing managerial capacity, that are efficiency of cost management shown by the rate of cost per total income $\left(\mathbf{C I}_{\mathbf{i t}}\right)$ and profitability shown by the rate of profitability per equity $\left(\mathrm{ROE}_{\mathrm{it}}\right)$. Similar to studies conducted by Louzis (2012) and Lobna Abid and et al., (2013), researchers express their expectation of a positive correlation for variable $\mathbf{C I}_{\mathbf{i t}}$ and negative correlation for variable $\mathbf{R O E}_{\mathbf{i t}}$.

Operational size: Relations between operational size and credit risk in theoretical and experimental studies conducted in the past shows an unclear outcome. Large size offers favorable conditions for commercial banks to invest in the improvement of credit procedure, quality of risk management and highly qualified human resources as well. Simultaneously, large operational sizes along with high market shares allow commercial banks to diversify their credit activities, thereby making contributions to minimizing the credit centralization risk (Louzis, 2012). 
Opposite relations between banking size and credit risk was reported in the researchers conducted by Salas and Saurina (2002) hay Hu et al., (2004). Nevertheless, large size and marker shares could help commercial banks reach the status of "Too big to fail (Note 1)", resulting in commercial banks' willingness of accepting higher risk in business and lending clients with higher risk degree for high interest rate. As a result, credit risk will be on a rise in the future. The author utilizes two variables to represent operational size of commercial banks composed of value of total assets $\left(\mathbf{S i z e}_{\mathbf{i t}}\right)$ and market shares $\left(\mathbf{M k p} \mathbf{p}_{\mathbf{i t}}\right)$.

Capital structure: Capital structure represents degree of financial leverage as well as degree of safety in commercial banks' business. Commercial banks under opration with large financial leverage and little equity are offen ready to accept higher risk in business for profit (Berger and Deyoung, 1997). Researchers conducted by Podpiera and Weill (2008) and Salas and Saurina (2002) also report the win-win correlation between financial leverage and credit risk. The rate of equity per total property of commericial banks $\left(\mathbf{C a p}_{\text {it }}\right)$ is used for representing capital structure's effect on the rate of NPL.

Table 1. Variables used in the research

\begin{tabular}{|c|c|c|c|}
\hline \multirow{2}{*}{ 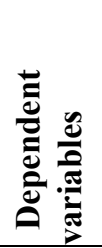 } & Variable & Description & Sign \\
\hline & Credit risk & Ratio of NPL [NPL outstanding/Total outstanding loans] & $\mathbf{N P L}_{\text {it }}$ \\
\hline \multirow{6}{*}{ 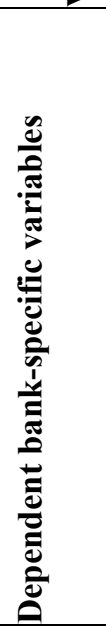 } & \multirow[b]{2}{*}{ Operational size } & Property size [Ln(Total assets)] & Size $_{\text {it }}$ \\
\hline & & $\begin{array}{l}\text { Market shares [Total assets of the commercial } b^{2} k_{i t} / \text { Total } \\
\text { assets of the whole system in the year } t \text { ] }\end{array}$ & Mkp $_{\text {it }}$ \\
\hline & Credit growth & $\begin{array}{l}\text { Outstanding balance growth [(Outstanding balance of period } t \\
- \text { Outstanding balance of period } t-1) / \text { Outstanding balance of } \\
\text { period } t-1]\end{array}$ & Bankergr $_{\text {it }}$ \\
\hline & \multirow{2}{*}{$\begin{array}{l}\text { Managerial } \\
\text { efficiency }\end{array}$} & Cost management [Total costs / Total income] & $\mathbf{C I}_{\text {it }}$ \\
\hline & & Profitability [ROE: Profit after tax/Average equity] & $\mathrm{ROE}_{\mathrm{it}}$ \\
\hline & Capital structure & Equity rate [Equity/Total assets] & $\mathbf{C A P}_{\text {it }}$ \\
\hline \multirow{3}{*}{ 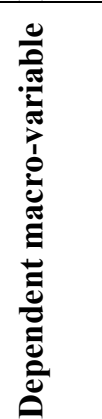 } & Economic cycle & Real GDP growth rate & RealGDP $_{\text {it }}$ \\
\hline & Interest rate & Average real Interest rate & RealIr $_{\text {it }}$ \\
\hline & Inflation & CPT growth rate of the year $t$ & $\operatorname{Inf}_{\text {it }}$ \\
\hline
\end{tabular}

\subsection{Research Model}

Model of Dynamic Panel Data approach (DPD (Note 2)) is recommended for implementation in studies conducted by Salas and Saurina (2002); Louzis (2012) with a view to reviewing the effect caused by time to credit risk due to Non-performing loan outstanding in the rate of Non-performing loans determined by the period of late payment of principal and/or interests of clients.

Initial equation of quantitative model is used as follows: 


$$
\mathrm{NPL}_{\mathrm{it}}=\alpha+\gamma \mathrm{NPL}_{\mathrm{i}, \mathrm{t}-1}+\beta \mathrm{X}_{\mathrm{it}}+\mathrm{u}_{\mathrm{i}}+\varepsilon_{\mathrm{it}},|\alpha|<1, \mathrm{i}=1, \ldots, \mathrm{N} ; \mathrm{t}=1, \ldots, \mathrm{T}
$$

Of which, $\mathrm{i}$ symbolizes Commercial Bank $\mathrm{i}, \mathrm{t}$ symbolizes the year of research. $\mathrm{X}_{\mathrm{it}}$ is $(\mathrm{kx} 1)$ vector representing explanatory variables used in the model, $\mathrm{u}_{\mathrm{i}}$ is undetermined effect of characteristic of each commercial bank, $\varepsilon_{\mathrm{it}}$ is statistical residual.

With an equation of researching dynamic approach using panel data, the above model will produce dishonest and biased statistics when utilizing normal statistical technique with panel data such as random-effect (Note 3) and fixed-effect (Note 4) or Pooled OLS (Note 5) because NPL $\mathrm{L}_{\mathrm{i},-1-1}$ will correlate with $\mathrm{u}_{\mathrm{i}}$. Hence, the author uses Generalized Moment of Method (GMM) with approach by one-step model launched by Arellano and Bond (1991). Accordingly, correlation between residual of $\mathrm{u}_{\mathrm{i}}$ and $\mathrm{NPL}_{\mathrm{i}, \mathrm{t}-\mathrm{l}}$ is solved by converting the equation 1 into the first-order difference.

$$
\Delta \mathrm{NPL}_{\mathrm{it}}=\alpha+\gamma \Delta \mathrm{NPL}_{\mathrm{i}, \mathrm{t}-1}+\beta \Delta \mathrm{X}_{\mathrm{it}}+\Delta \varepsilon_{\mathrm{it}}
$$

By this way, we may avoid problems involving to correlation between $\mathrm{u}_{\mathrm{i}}$ and $\varepsilon_{\mathrm{it}}$ that could occur. Also, in order to ensure the research of explanatory variables' dynamic effect on commercial banks' Non-performing loan, the form of lagged variable is widely used. Studies conducted by Louzis (2012) and Berger and DeYoung (1997) show that the one-year period is sufficient to perceive lagged variables' effect on credit risk in the next period.

Original regression model with approaching method of Arellano and Bond (1991) which applies GMM will use exogenous variables for explanation of change in commercial banks' the ratio of Non-performing loan.

$$
\begin{gathered}
\Delta \mathrm{NPL}_{\mathrm{it}}=\alpha+\gamma \Delta \mathrm{NPL}_{\mathrm{i}, \mathrm{t}-1}+\beta_{1} \Delta \mathrm{GDP}_{\mathrm{t}-1}+\beta_{2} \Delta \text { Realir }_{\mathrm{t}-1}+\beta_{3} \Delta \mathrm{Inf}_{\mathrm{t}-1}+\Delta \varepsilon_{\mathrm{it}} \\
|\alpha|<1, \mathrm{i}=1, \ldots, 20 ; \mathrm{t}=1, \ldots, 9
\end{gathered}
$$

Of which

$\Delta \mathrm{GDP}_{\mathrm{t}}$ is real GDP growth rate of the year $\mathrm{t}$

$\Delta$ Realir $_{t}$ is the change of real lending rate in the year $t$ compared to the previous year.

$\Delta \operatorname{Inf}_{\mathrm{t}}$ is the change of inflation rate in the year $\mathrm{t}$ compared to the previous year.

Next, for determining effects of characteristics during operation of commercial banks with credit risks, the selected micro variables are used in the equation (3). Judson and Owen (1999) think that putting a large number of tool variables into the model through lagged variables in the dynamic regressive model may cause the fact that the model's result fails to make the most of information from datasets. The author will make the choice of restricted GMM approach (Note 6) by putting in turn each micro variable into the original regressive model with one-year lagged value in order to clarify effects on credit risk. At last, dynamic regressive model for panel data under the GMM, based on approach of Arellano and Bond (1991) is researched and used as follow:

$$
\begin{gathered}
\Delta \mathrm{NPL}_{\mathrm{it}}=\alpha+\gamma \Delta \mathrm{NPL}_{\mathrm{i}, \mathrm{t}-1}+\beta_{1} \Delta \mathrm{GDP}_{\mathrm{t}-1}+\beta_{2} \Delta \text { Realir }_{\mathrm{t}-1}+\beta_{3} \Delta \operatorname{Inf}_{\mathrm{t}-1}+\beta_{\mathrm{j}} \mathrm{X}_{\mathrm{i}, \mathrm{t}-1}+\varepsilon_{\mathrm{it}} \\
|\alpha|<1, \mathrm{i}=1, \ldots, 20 ; \mathrm{t}=1, \ldots, 9 ;
\end{gathered}
$$

Of which, $X_{i t}$ represents selected variables to explain credit risk in business of commercial banks. Notwithstanding variable Size $_{\text {it }}$ which is used with value in the year $t$ without lagged variables to assess direct effects of property size on credit risk of commercial banks ((Louzis, 2012; Lobna Abid and associates, 2014), remaining variables are used with a lag time of one year with assumption that current value of variables reflecting operational characteristics of commercial banks will not make direct and immediate effort on commercial banks' credit risk in the year due to impacts of accounting records as well as delays in management decisions (Berger and DeYoung, 1997; Louzis, 2012).

\subsection{Results}

The appropriateness of instrumental variables significantly conditions the stability and effectiveness of GMM. The writer thus carried out Sargan test to identify the overall stability of instrumental variables, as recommended by Arellano and Bond (1991); and Arellano and Bover (1995). Besides, the residuals must insure the nonexistence of first-order serial correlation. This was tested based on the approach of Arellano and Bond (1991). The employed instrumental variable would be nonsense when exists a higher-order serial correlation among single differentials of the model's residuals.

Provided such test findings as described in the table, p-values of all models through AR test (1) statistically hint at the presence of serial correlation among single differentials of the model's residuals, meanwhile no p-value through AR test (2) signals a higher order serial correlation among single differentials of residuals. 
That far it be from Sargan-test based p-values to deny the original hypothesis of the appropriateness of instrumental variables implies the likely reliability, suitability and stability of regression results.

Table 2. Results of the regression model

\begin{tabular}{|c|c|c|c|c|c|c|c|}
\hline Variables & $\begin{array}{c}\text { Original } \\
\text { model }\end{array}$ & Model 2 & $\begin{array}{c}\text { Model } \\
3\end{array}$ & del 4 & Model 5 & Model 6 & Model 7 \\
\hline \multirow[t]{3}{*}{$\Delta \mathbf{N P L}_{\mathrm{i}, \mathrm{t}-1}$} & $0.2938 * * *$ & $0.26777 * * *$ & $0.33558 * * *$ & $0.28871^{* *}$ & $0.35441 * * *$ & $0.29444 * * *$ & $0.3186^{* * *}$ \\
\hline & [0.10816] & [0.12204] & [0.09438] & [0.1180] & {$[0.11766]$} & [0.11144] & [0 .1115] \\
\hline & \multicolumn{7}{|c|}{ Macro- economic variables } \\
\hline \multirow[t]{2}{*}{$\Delta \mathbf{G D P}_{\mathrm{t}-1}$} & $0.6315^{* *}$ & $0.47226^{* *}$ & $0.4939 * *$ & $0.8055^{* * *}$ & $0.7666^{* *}$ & $0.4848^{*}$ & $0.7680^{* * *}$ \\
\hline & [0.3119] & [0.33203] & {$[0.21021]$} & [0.2395] & {$[0.3161]$} & {$[0.3265]$} & {$[0.2605]$} \\
\hline \multirow[t]{3}{*}{$\Delta$ Realir $_{\mathrm{t}-1}$} & 0.0418 & 0.03392 & 0.0389 & 0.4409 & 0.0475 & 0.0397 & 0.0487 \\
\hline & {$[0.3334]$} & {$[0.0323]$} & [0.03477] & {$[0.0325]$} & {$[0.0348]$} & {$[0.0301]$} & [0.0313] \\
\hline & \multicolumn{7}{|c|}{ Micro-economic variables } \\
\hline \multirow[t]{2}{*}{$\operatorname{ROE}_{i, t-1}$} & & -0.00189 & & & & & \\
\hline & & [0.02905] & & & & & \\
\hline \multirow[t]{2}{*}{$\mathbf{C A P}_{\mathrm{i}, \mathrm{t}-\mathbf{1}}$} & & & $-0.0776 * * *$ & & & & \\
\hline & & & [0.02965] & & & & \\
\hline \multirow[t]{2}{*}{ SIZE $_{\text {it }}$} & & & & 0.5493 & & & \\
\hline & & & & [0.6421] & & & \\
\hline \multirow[t]{2}{*}{ Mkpo $_{i, t-1}$} & & & & & $0.1582 *$ & & \\
\hline & & & & & [0.1188] & & \\
\hline \multirow[t]{2}{*}{$C \mathbf{I}_{\mathbf{i},-1}$} & & & & & & -0.01338 & \\
\hline & & & & & & {$[0.0290]$} & \\
\hline BankCrgr- & & & & & & & $0.0631 * *$ \\
\hline $\mathrm{i}, \mathrm{t}-\mathbf{1}$ & & & & & & & {$[0.0881]$} \\
\hline \multirow[t]{2}{*}{ Cons } & -1.9417 & -1.3950 & -1.8476 & -9.1593 & -2.2633 & 1.4893 & -2.2802 \\
\hline & [1.8788] & [1.8872] & [1.9048] & [7.8494] & [1.8371] & [1.1152] & [1.6396] \\
\hline \multirow[t]{2}{*}{$\mathbf{A R}(\mathbf{1})$} & -2.2765 & -2.2738 & -2.1965 & -2.3126 & -2.1623 & -2.0895 & -2.1632 \\
\hline & $(0.0228)$ & $(0.0230)$ & $(0.0281)$ & $(0.0207)$ & $(0.0306)$ & $(0.0367)$ & [0 .0305] \\
\hline \multirow[t]{2}{*}{$\mathbf{A R}(2)$} & 0.68325 & 0.28392 & 0.5992 & 0.5041 & -0.7664 & -0.1404 & 1.0847 \\
\hline & $(0.4944)$ & $(0.7765)$ & $(05490)$ & $(0.6142)$ & $(0.4434)$ & $(0.8883)$ & {$[0.2761]$} \\
\hline \multirow[t]{2}{*}{ Sargan test } & 29.14285 & 25.9137 & 28.5555 & 27.6216 & 26.1246 & 34.0568 & 27.4254 \\
\hline & $(0.3044)$ & $(0.4679)$ & $(0.3317)$ & $(0.3773)$ & $(0.4563)$ & $(0.1336)$ & $(0.3873)$ \\
\hline Obs & 110 & 105 & 108 & 110 & 108 & 105 & 104 \\
\hline
\end{tabular}

The above table presents the result of regression model surveying determinants of credit risk among Vietnam banks over the period 2006 - 2014, using the generalized method of moments through Arellano and Bond (1991)'s approach.

Characte stand for significance levels of $1 \%, 5 \%$ and $10 \%$.

Those figures inside [.] denote the standard deviations of factors

Those figures inside (.) denote P-value of tests

Sargan Test and Hansen test are displayed in order to test the stability and reliability of the regression model 
NPLit $=$ Ratio of non-performing loans; $R O E=$ Profit after tax / Weighted equity; CI = Total cost / Total Income; $C A P=$ Equity / Total capital; BankCrgr $=$ Growth rate of outstanding loan; Mkpo = Market position; $\operatorname{lnSize}=\mathrm{Ln}$ (Loan size); RealGDP = Real credit growth; RealIr = Real average interest rate;

Source: Calculated by these authors

The results allow us to conclude that:

\section{Firstly, concerning the impact of macro-economic factors on Vietnam banks' credit risk}

Economic cycle: It is quantitatively found that $\mathbf{G D P}_{\mathbf{t}-1}$ of the previous period has a clear and positive correlation with credit risk exposed by Vietnam banks. This indeed comes against the expectations of historical researches, which predominantly discovered the negative interrelations between economic growth and credit risk. However, the finding somewhat fits the case of Vietnam's economy, which immensely depends on bank loan capital with a credit growth "boiled" by soaring economy. In parallelism, misallocation of capital to high-risk funds potentializes the eventual incurrence of credit risk. General Statistics Office reported Vietnam's ICOR (Note 7) to persist at the upper position among its regional counterparts, which indicates a poor performance of investment capital use. Non-performing loan ratio, which comes in 1-year latency after GDP, subsequently bears a positive correlation with GDP, as a result of credit quality impairment during economic upsurge.

Real interest rate: Quantitative results show changes in real interest rate of the last preceding year (Realir $\left.r_{t-1}\right)$, all of which have positive values, as expected by historical researches but no sufficient statistical value to be admitted. This is understandable in the sense that Vietnam banks' interest rate movements do not adhere to the market changes, but are partly bound with bureaucratic rules, while the rapid and instable move of inflation under a developing economy blunts the real interest rate as an echo of real costs of customers. At the same time, the major part of bad debts incurred from unsound capital utilization of state-owned groups and corporations, who are privileged with low-rate loans, is an accomplice in the volatile relation between real interest rate and credit risk.

\section{Secondly, regarding the impact of micro economic factors on Vietnam banks' credit risk}

Previous period credit risk: Credit outcome confirms the existence of an inertial dynamic relation among Vietnam banks, since all models found positive correlation with high significance. It hints us at the inefficiency of Vietnam banks' credit risk management, which would exacerbates credit portfolios if the overdues and bad debts incurred in previous periods remained unsolved and uncollected timely, turn healthy loans into write-offs and trigger the loan reclassification.

Profitability: Estimations suggest that if banks perform a higher profitability, which indicates a more effective management competence, credit risk will be mitigated. However, such assumed relation has not sufficient statistical basis enough to be recognized. It is probably because of the wide difference and variation of profitability among banks under research. Furthermore, against the backdrop of economic and particularly financial globalization, Vietnam banking institutions are increasingly looking for transformation into banking and finance groups to produce diversity of financial services which are more susceptible to macro-economic uncertainty. This pushes profitability a further distance from the dominion of credit portfolio.

Cost management effectiveness: It is approximately suggested that a ratio of cost per total income increasing in the last preceding period $\left(\mathbf{C I}_{\mathbf{i t}}\right)$ would push up NPL of the next period. This sounds conforming to the discovery of other researchers such as Salas and Saurina (2002); Louzis et al (2011) or Lobna Abid (2014). An increasing cost per total income implies the misperformance of cost management and managerial competency of institutions. Mismanagement results in misperformance of evaluation, measurement, control and supervision of credit portfolio, and eventually a greater exposure to credit risk.

Capital structure: The variable of $\mathbf{C A} \mathbf{P}_{\mathrm{i}, \mathrm{t}-\mathrm{1}}$, which denotes equity weighted by total asset, is seen correlating negatively with credit risk of the following period. This observation totally matches the expectation that a declined financial leverage means an impairment of banks' credit risk taste, upon which banking managers would be reluctant to grant loans to even highly credit-rated borrowers, so as to minimize loan default. The period from 2006 to 2014 observed a hasty credit growth of Vietnam banks, as a response to requirements on minimum capital adequacy, and in attempt ion to heighten potential and competitiveness in the context of financial globalization and emergence of world's large financial institutions. Such condition enables banks' operation in a greater safety and further insures them with sufficient capital to invest, enhance quality, standard and technique of credit risk management, access international practices and mitigate risks in the time to come. 
Scope of operation: Operation scope of a bank is represented by its Size as well as its market position in comparison to other banks (Mkpo). Regression model points out that such bank of superior scale and market position is more prone to the prospect of rising credit risk, affirming the existence of such theory called "to big to fail" in Vietnam's banking system. Accordingly, big institutions have become more easy-going lenders; hence increases credit exposure in coming time. Effect of state-shared banks also presents an explanation. In Vietnam, they are the largest banks all over the system (Agribank, Vietinbank, Vietcombank, BIDV), where the State owns the major controlling share (this "big four" had occupied 49\% total market share, by ending 2014). However, their operation efficiency has been seen with instability and impairment over years, partly because the compelled loans as directed bureaucratically ended up in insolvency. Moreover, improper disposal of non-performing loans worsening operation efficiency, in combination with the moral hazard, has pushed up the bad debts and watered down the profitableness of State's capital in these banks. Another attribution should be referred to the recent trend among small-sized banks, who have over-focused on scale at the expense of credit quality; hence undesirable impacts on credit performance.

Credit growth: To a high statistical significance, it can be concluded from the quantitative model that, a hasty expansion of credit scale would bloat the risk in banking activities. This conclusion shares idea with the past researchers in that the loan growth under tremendous competitive pressure will stimulate setting down of credit standard, then drive the capital flow into risk-prone sectors, and eventually boost the non-performing loan ratio. Prior-2011 period witnessed the rocketing upsurge in credit among banks, as a result of heavy demand for capital from economic entities. Still, a considerable part of credit flow was poured in high-risk non-manufacturing industries such as securities and real estate. Capital misusage, together with relaxing post-lending supervision of commercial banks, is the reason for credit risk exacerbation on the threshold of economic recession.

\section{Conclusions}

By review and assessment of actual credit risk situation, we carried out identifications and qualitative analysis of potential factors possibly affecting credit risks in business activities of Vietnamese commercial banks. Then, based on previous studies, we used panel data and dynamic regression model to control the existence of inertial effects though time of credit risks and Generalized Moment of Method and the approach of Arellano and Bond (1991) to analyze factors affecting credit risks of commercial banks in Vietnam in the period 2006-2014 including bank-specific factors (internal factors) as well as macro factors (external factors).

Regarding internal factors, explanatory variable which has the most stable statistical significance in all estimation models is credit risk variable representing the existence of inertia effects of credit risk management capacity as well as credit growth variable representing credit growth of commercial banks. Negative-positive correlation with credit growth variable shows that capital use, risk control and management of Vietnamese commercial banks are ineffective. The results also indicate that commercial banks with large scale and market share in Vietnam's commercial bank market seem to ready to accept higher risks in credit operations as well as influenced by requirements for loans for state-owned corporations in which credit risks are negatively affected due to operation characteristics. Besides, quick equity increase also helps commercial banks enhance tolerance to credit risks and invest in suitable risk management facilities.

Regarding macro factors, two factors considered are GDP growth and real interest rate. The estimation results show a positive correlation between GDP growth and strong statistical significance and credit risks, reflecting impact of economic cycle on repayment capacity of borrowers while the impact of real interest rate on credit risks is negligible.

The significant of this study is the scope of the obversations and the period of time compared to pevious research about commercial banks in Vietnam. This study gives more comprehensive views to researchers and managers in banking about the credit risk factors. This is helpful for implementing other applied researchs, or taking the appropriate measures to improve risk management in Vietnammemse commercail banks. In addition, the study helps bank managers having a more general vision of the credit risk, hence, enabling the prevention of adverse factors which affects the credit risk in banking operation. Finally, the research can be used as research material and empirical evidence about credit risk management in teaching and research.

\section{References}

Ahbiman Das, \& Ghosh, S. (2007). Determinants of Credit Risk in Indian State-owned Banks: An Empirical Investigation. Economic Issues Journal Articles, Economic Issues, 12(2), 27-46.

Ahlem Selma Messai, \& Fathi Jouini. (2013). Micro and Macro Determinants of Non-performing Loan. International Journal of Economics and Financial Issues, Econjournals, 3(4), 852-860. 
Ahmad, N., \& Ariff, M. (2007). Multi-country study of bank credit risk determinants. International Journal of Banking and Finance, 5(1), 135-152.

Arellano, M., \& Bond, S. (1991). Some tests of specification for panel data: Monte Carlo evidence and an application to employment equations. Review of Economic Studies, 58, 277-297.

Arellano, M., \& Bover, O. (1995). Another look at the instrumental variables estimation of error components models. Journal of Econometrics, 68, 29-51. http://dx.doi.org/10.1016/0304-4076(94)01642-D.

Baltagi, B. (2008). Econometric Analysis of Panel Data (4th ed.). John Wiley \& Sons, Ltd., Chichester, UK.

Berge, T.O., \& Boye, K.G. (2007). An analysis of bank's problem loans. Norges Bank. Economic Bulletin, 78, 65-76.

Berger, A., \& DeYoung, R. (1997). Problem loans and cost efficiency in commercial banks. Journal of Banking and Finance, 21, 849-870.

Bikker J. A., \& H. Hu. (2002). Cyclical Patterns in Profits, Provisioning and Lending of Banks and Procyclicality of the New Basel Capital Requirements. BNL Quarterly Review, 55, 143-175.

Bofondi, M., \& Ropele, T. (2011). Macroeconomic Determinants of Bad Loans: Evidence from Italian Banks. Occasional Papers, 89.

Bonfim, D. (2009). Credit risk drivers: evaluating the contribution of a firm level informationand macroeconomic dynamics. Journal of Banking and Finance, 33(2), 281-299. http://dx.doi.org/10.1016/j.jbankfin.2008.08.006

Can Van Luc. (2013). Risk management in Vietnamese commercial banks - Current situation and solutions. Presented at the seminar of risk management in 2013 held by IDG, CICB and BIDV, September, 2013.

Castro, V. (2013). Macroeconomic determinants of the credit risk in the banking system: The case of the GIPSI. Economic Modelling, 31, 672-683.

Casu, B., Girardone, C., \& Molyneuxra, P. (2006). Introducing to Banking. Financial Times, Prentice Hall, USA.

Dell'Ariccia, G., \& Marquez, R. (2006). Lending Booms and Lending. The Journal of Finance, 51(5), 2511-2546.

Demirguç-Kunt, A., \& Detragiache, E. (1998). The determinants of banking crises and developed countries. IMF Staff Papers, 45(1), 81-109.

Fofack, H. (2005). Nonperforming Loan in Sub-Saharan Africa, Causal Analysis and Macroeconomic Implications. World Bank Policy Research Working Paper No. 3769.

González-Hermosillo, B., Pazarbasioglu, C., \& Billings, R. (1997). Determinants of Banking System Fragility: a Case Study of Mexico. IMF Staff Papers 44, 295-314. http://dx.doi.org/10.2307/3867561

Grigori Fainstein. (2011). The Comparative Analysis of Credit Risk Determinants, In the Banking Sector of the Baltic States. Review of Economic and Finance, 1, 20-45.

Ha Thi Sau. (2013). Settlement of non-performing loans in the process of restructuring the system Vietnamese CBs. Banking Magazine, No. 131.

Hasna, C., \& Zied, F. (2014. Credit risk determinants: Evidence from a cross - country. Research of International Business and Finance, 33, 1-16.

Hu, J., Yang, Li., \& Yung-Ho, C. (2004). Ownership and non-performing loans: evidence from Taiwan's banks. Developing Economies, 42, 405-420. http://dx.doi.org/10.1111/j.1746-1049.2004.tb00945.x

Jakubík, P. (2007). Macroeconomic environment and credit risk. Czech Journal of Economics and Finance, 57(1-2), $60-78$.

Jiménez, G., \& Saurina, J. (2004). Collateral, type of lender and relationship banking as determinants of credit risk. Journal of Banking and Finance, 28, 2191-2212. http://dx.doi.org/10.1016/j.jbankfin.2003.09.002

Jiménez, G., \& Saurina, J. (2006). Credit cycles, credit risk and prudential regulation. International Journal of Central Banking, 2(2), 65-98.

Judson, R., \& Owen, L. (1999). Estimating dynamic panel data models: a guide for macroeconomists. Economics Letters, 65, 9-15. http://dx.doi.org/10.1016/S0165-1765(99)00130-5

Kieu Huu Thien, \& Phan Manh Hung. (2014). Ownership structure and eperformance of Vietnamese commercial banks. Report on panorama of banking sector in 2013, Banking Academy. 
Nguyen Thi Nhung. (2013). Solving risk problem for sustainable development of Vietnamese CBs. Banking Technology Magazine, (1-2).

The State Bank of Vietnam. (2012). Decision on promulgation of Action Plan of Banking sector for implementing Project "Restructuring the system of credit institutions in the period 2011-2015. Decision No. 734/QD-NHNN dated April 2012.

The State Bank of Vietnam. (2014). Regulations on limits, safety rate in operations of credit institutions and foreign bank branches. Circular No. 36/2014/TT-NHNN

\section{Notes}

Note 1. The concept of "Too-big-to-fail" implies organizations with size, degree of complexity and connection, influence are so large that the market and economy could be incurred negative effect in case of collapse of those organizations. (Ben Bernanke, 2010). Therefore, managerial agencies will give more priorities and provide support if they have difficulties

Note 2. Dynamic Panel Data approach

Note 3. Random-effect

Note 4. Fixed-effect

Note 5. Pooled OLS

Note 6. Restricted GMM approach

Note 7. ICOR: Incremental Capital Output Ratio, reflecting the efficiency of the use of investment capital of the economy in a specific period. 